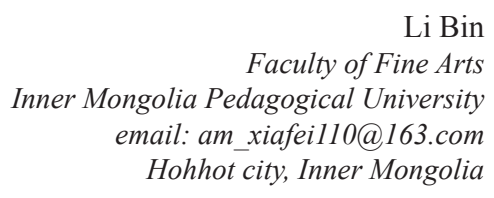

ORCID 0000-0003-0637-1497

DOI: 10.36340/2071-6818-2019-15-4-136-146I

\title{
The Humanistic Spirit in Sculptor's Work (on the Example of Li Xiangqun's work)
}

Summary. Li Xiangqun, the famous Chinese sculptor, managed to evolve his creative style developing a confident and fine ability to create forms, a special and distinctive perspective on reality, skillfully mastering the refined expressive language of sculpture and creating sculptural works filled with spiritual value, the spirit of the times and a sense of humanism. In this paper, the importance of humanistic factors in the fine sculptural art is emphasized by analyzing a part of Li Xiangqun's works, transferring the experience of understanding the style and power of involvement of Li Xiangqun's sculpture to the reader, as well as the experience of sensory feelings of humanistic elements in Li Xiangqun's work. The embodiment of humanistic values in the material form is the spirit and quintessence of figurative sculpture, this is what distinguishes figurative sculpture as a phenomenon from the refined basic image of reality in the form of sculpture. This spirit is the parameter with which it is necessary to correlate the sculptor's work. The works of Li Xiangqun require the highest attention to ourselves, they are a classic example of the embodiment of the elements of humanism in sculpture. Li Xiangqun has been universally recognized as a leader and devotee of contemporary Chinese fine sculpture; he has made an indisputable contribution to the development of modern Chinese fine sculpture and its humanistic spirit.

Keywords: Li Xiangqun, figurative sculpture, the figurative language of sculpture, humanistic spirit.

Regardless of whether we consider a sculptural work from the standpoint of analyzing the form and meaning or spiritual content, the spirit of humanism is one of its most important parts, a kind of its quintessence. A creator who cannot express feelings or does not know how to do it in his works is an unfortunate and somewhat tragic sight due to the fact that, then, his work loses all meaning. However, at the same time, art is not only the best form of expressing the creator's feelings but also a certain measure of his responsibility to society.

Something in which there is neither feeling nor spirit cannot be art, and the spirit of humanism is precisely what runs through the human being and his whole life. While being interpreted through the prism of sculpture, it acquires a visible and tangible 


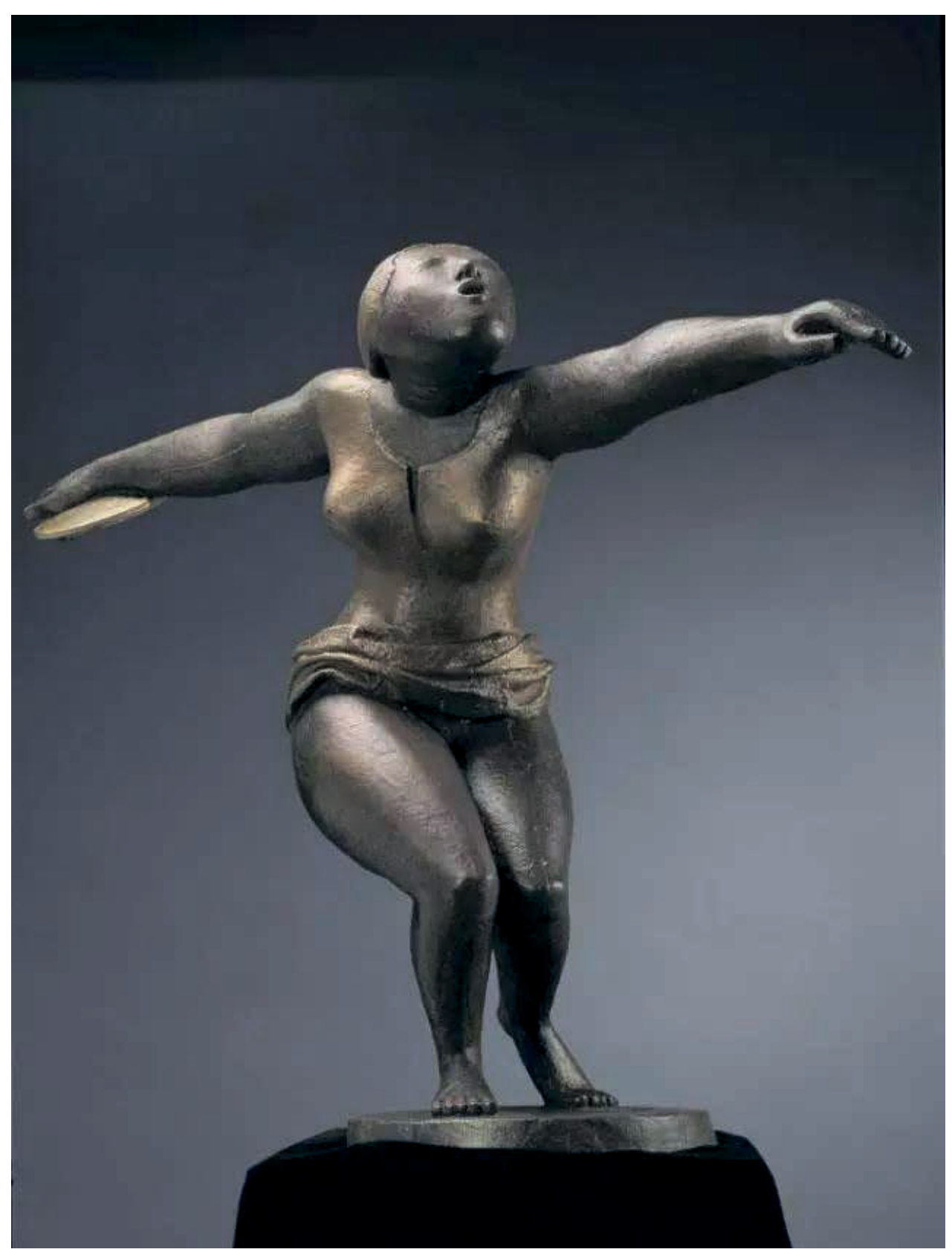

Ill. 1 Eternal Revolution 


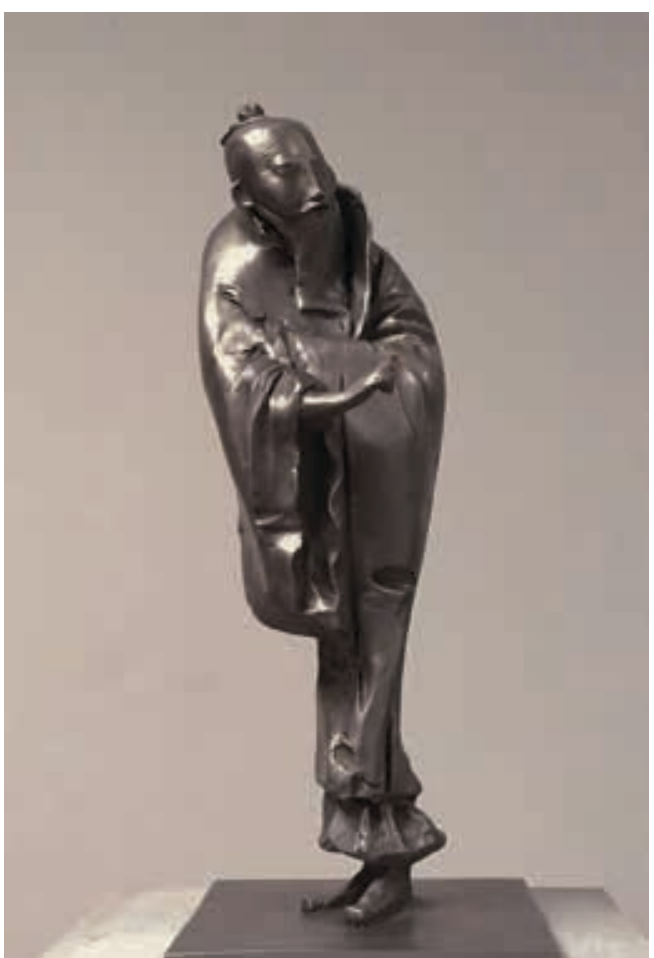

Ill. 4 Heaping Clouds and Snow expression in the form of sculptural work. The humanistic spirit contained in the work is what determines the success of this work, it is some kind of soul which the author puts into it.

Li Xiangqun's creative work is one of the leaders in modern figurative sculpture in China. In it, the sculptor has never focused on a superficial formal expression of content, in his case, the process is reversed: the author pays great attention to the humanistic spirit of his work, the expressive forms are defined by it. Having extensive historical knowledge, at one point he turned to the experience of the Rodin era, many outstanding creators of which achieved heights precisely owing to the ability to express vast philosophical ideas in their works and capture the breathing of the spirit of the time. That is what the true value, the essence of the art of sculpture is.

Li Xiangqun has managed to combine the elements of the Eastern xiěyì style and the anatomical accuracy of the Western school, creating an unmatched, beautiful in its own way style in which the language and spirit of the time are reflected.

In his work Eternal Revolution (Ill. 1), Li Xiangqun not only portrayed a discus thrower frozen at the time of the throw but also managed to symbolically show the energy, the vitality of humankind and the wonderful competitive spirit of the Olympic movement. If we compare this sculpture with the famous The Discobolus of Myron, which came to us from Ancient Greece, we will see that, in the Eternal Revolution, the sculptor was able to express the spirit of the time without losing the grace of classical Eastern sculpture. The thrower and her discus together form a spatial sculpture in which the moment a second before the throw froze as if it was a moment of universal harmony in which we see a spatial image of the galaxy rotation. This is a magnificent symbol of the continuity and eternal energy of mankind and the Olympic movement, a symbol of rebirth, which embodies the philosophy of the East.

Another noteworthy work by Li Xiangqun is Shanxu (Ill. 2), which combines the classic Western form with the subtle grace of deep Eastern content. The sculpture shows an image of a simple and spiritualized girl, the smooth features of her face and eyes, the corners of which are slightly upwards, create a feeling of silence and 


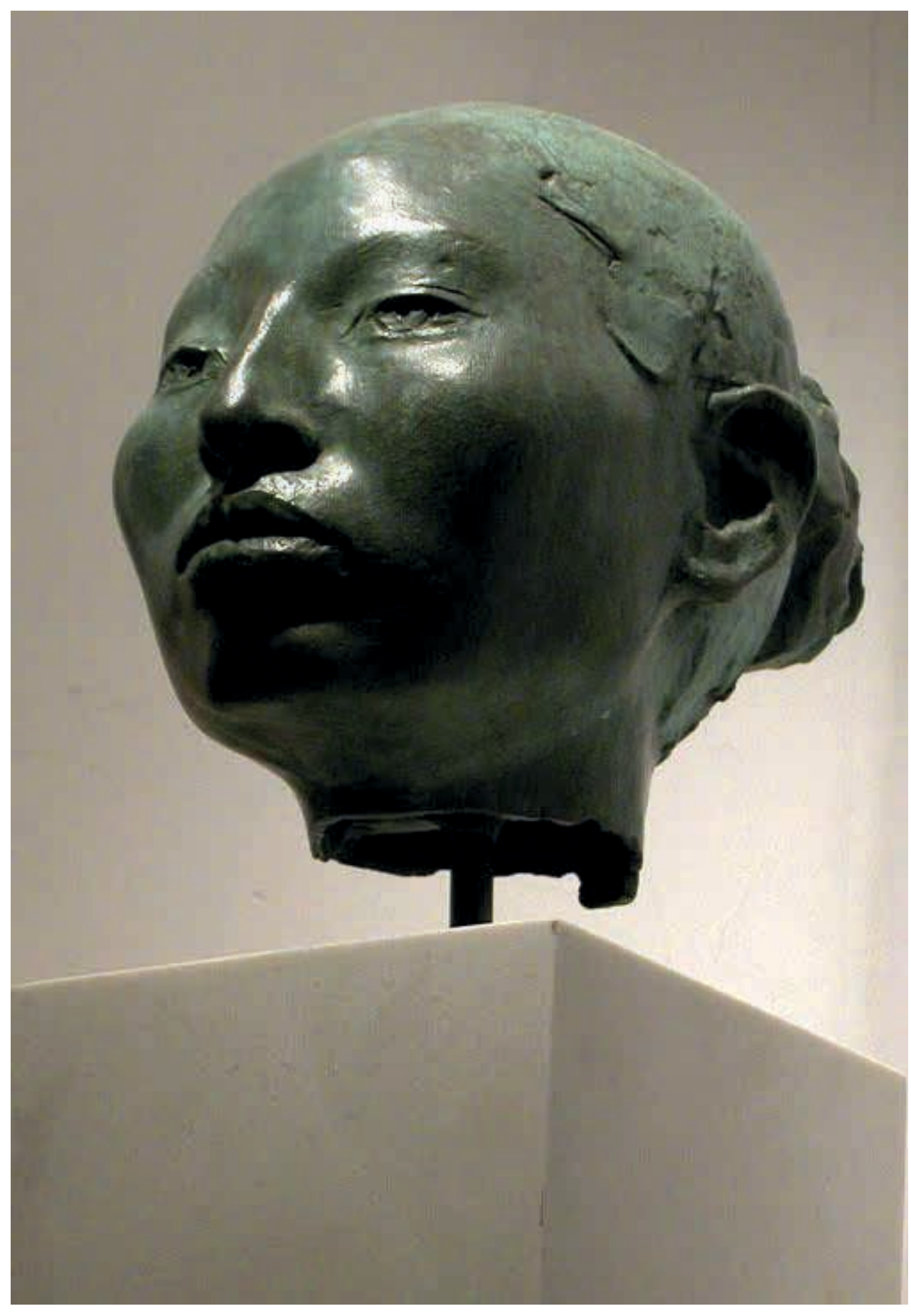

Ill. 2 Shanxu 


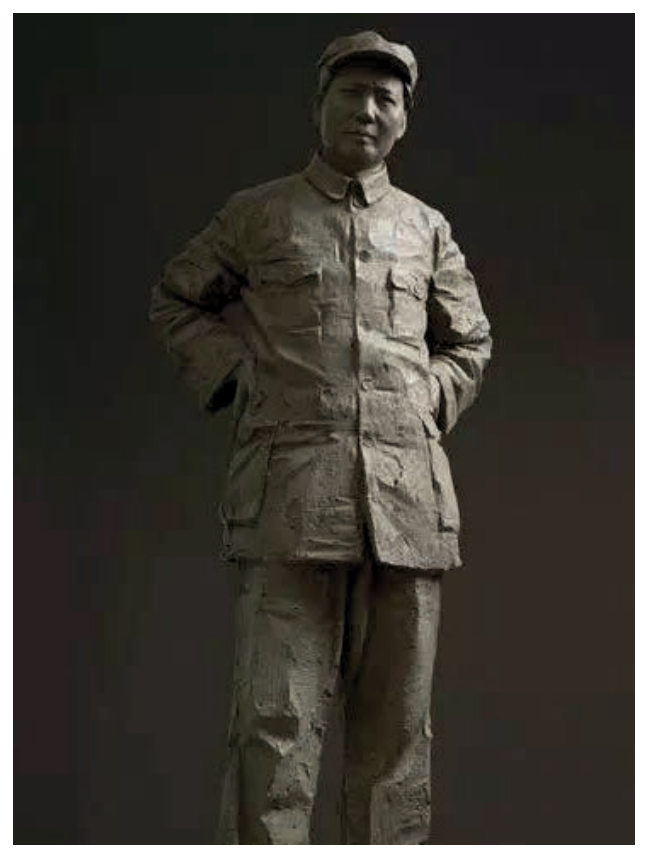

Ill. 3 Red Star Over China

thoughtfulness, conveying an aesthetically magnificent image of an oriental girl with her own special temperament. Looking at Shanxu, we can easily see that the most accurate depiction of reality is the basis of Li Xiangqun's style.

Having developed and mastered a special expressive language in sculpture, Li Xiangqun has created a distinctive style in art, at the same time trying to find a humanistic spirit in his work. His very characteristic works have attracted the attention of sculptors around the world and received recognition and awards at major international exhibitions, which is one of the reasons why he has become one of the most recognizable people among Chinese sculptors.

Red Star Over China (Ill. 3) is a book by American journalist Edgar Snow. These are his biographical notes in which he truthfully and with his usual revolutionary idealism described the events of the Great Military Campaign of the Red Army and the Yan'an Meeting. Mao Zedong served as the prototype of the man depicted in the sculpture of the same name, which reflected an image of the revolutionary idealism of the Western left intellectuals. The image created by him is largely inspired by the personality of Mao Zedong; however, this is not just an image of a historical character - the sculptor created an image focusing not on the political greatness of an individual, but on his personality, true character, even named the work allegorically with particular thoroughness conveying the psychological state, Mao's experiences, which makes this image different from the everyday reality. The sculptor managed to convey the moment of Mao's thoughtful and melancholy state in order to better convey and emphasize his true image as a person because, whether he is a prince or a pauper, his inner world is the most important thing in him. That is why this image of Mao Zedong is so different from the modern, repeatedly popularized and symbolized image of Mao; there is a difference in the psychological depth of the image. Creating this sculpture, the sculptor spared no effort in field research. He traveled to Shanbei, Zuan Yaodong, walked through Chairman Mao's places of fame, read a huge number of memoirs and studies on Mao Zedong, both Chinese and Western; he managed to achieve incredible authenticity and psychological truthfulness. If we don't have a desire for true knowledge and comprehension of history, no definite and clear historical consciousness can develop, and that is the reason why we need to turn to the 


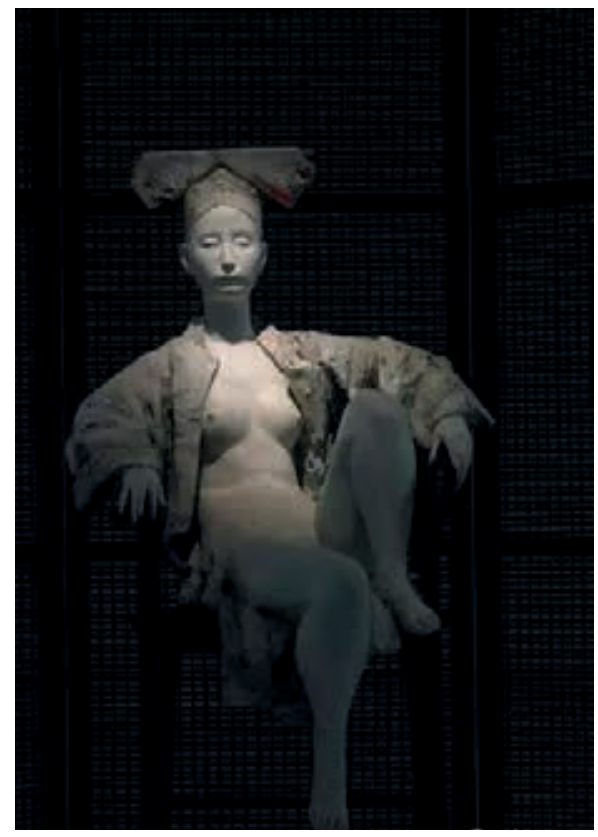

Ill. 6 Wang Meng

image of Mao Zedong again and again in order to better comprehend the modern historical fate of China.

The sculptor's next work, Heaping Clouds and Snow (Ill. 4), depicting Empress Cixi, is notable for the fact that in it the sculptor demonstrates another facet of his fine talent as a sculptor. As a rule, many artists and sculptors portraying negative historical figures do this in a caricatured manner. Here, for the first time, Li Xiangqun applied a new method of depicting historical characters, calling it Yunsan Syuesyao (Chinese: melting clouds and snow). It allowed him to show his interpretation of the ups and downs of Cixi's ambiguous personality. Of course, in some contemporary art movements, a thoughtless passion for form gave rise to "art for art", replacing the ideological content. Nevertheless, Li Xiangqun managed to weave the authentic spirit of the classics into the form of modern art and, from his experience, to show the deep rational experience of connecting sculptural forms of modern art and its contents. It can be said that this is the greatest power of Li Xiangqun's creative heritage, not just a sophisticated technique, but also a deep humanistic spirit that is manifested in the content of his sculptures.

The recent Li Xiangqun's series of works, Four Masters from Yuan Dynasty, became an even greater manifestation of the sculptor's respect for the spirit of traditional oriental art. Based on his perception of culture and art, Li Xiangqun has created images. For instance, Huang Gongwang (Ill. 5), whose pose expresses that he is creating a painting as if not with a brush, but with an idea, emphasizing the desire of Chinese traditional painting for ideology; or Wang Meng (Ill. 6), who is depicted lying on his side in idle contemplation, as if he was deeply imbued with the conceptions and ideas of ancient wise men, as if it was a pause from composing a poem, rushing into the past, hiding from the hustle of the present.

In recent years, Li Xiangqun has shown an increasing interest in the culture and history of China. On the basis of his point of view, he is breathing it into the symbolic images of ancient cultural figures, allowing them to re-enter the lives of modern people and form an understanding of the multilateral connection of antiquity, modernity, man and of self.

Conclusion. A work of art is the embodied spirit of humanity, which is why we say that the material should be the embodiment of the spiritual, otherwise art as such loses all meaning. Works of art must contain the spirit and sensual tastes of people due to the 


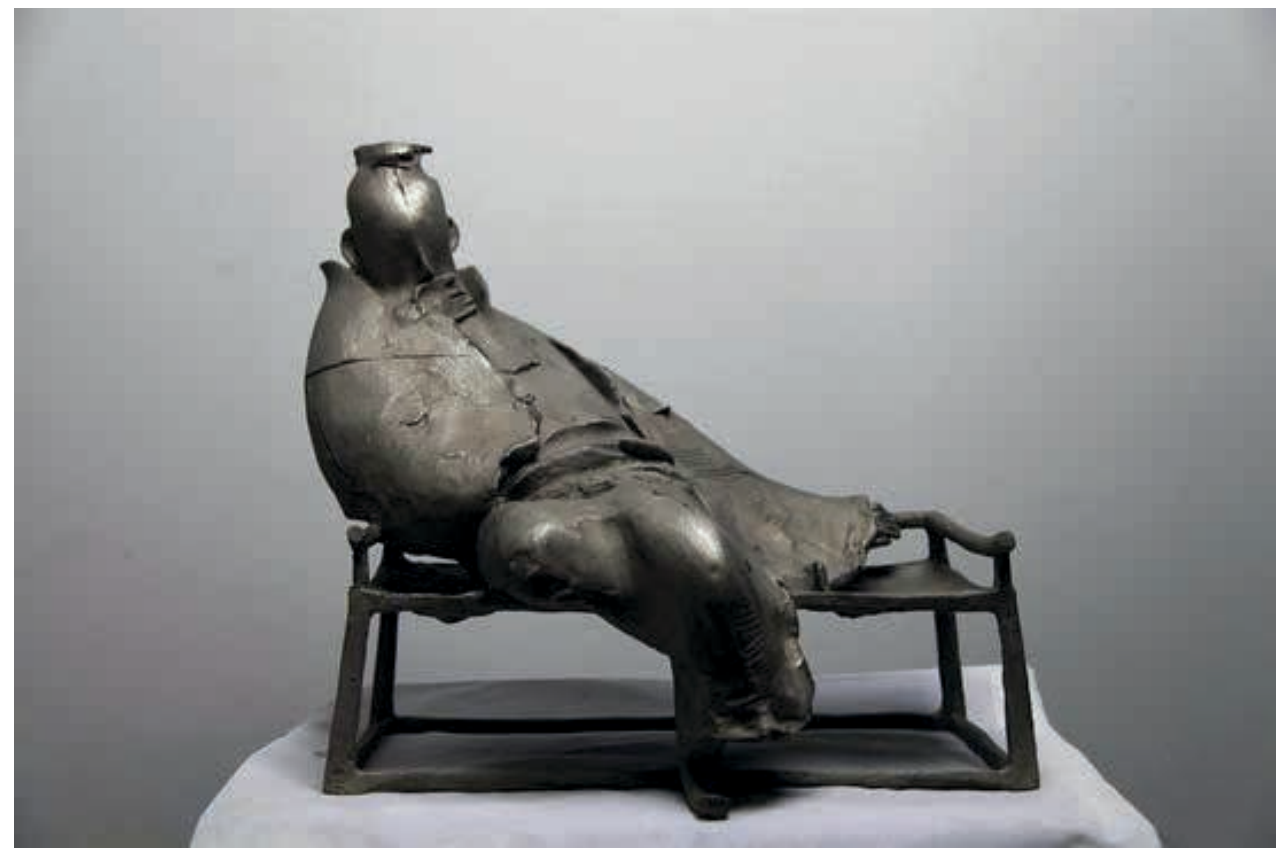

Ill. 5 Huang Gongwang

fact that the humanistic feeling is a kind of soul of sculptural work. If to look at artistic creativity in such a way, like at a bearer of the spirit, then its forms and its language become extremely important. We can say that using the language of sculpture forms, one can directly convey spiritual, philosophical concepts, emotions, feelings of humanism. Filling a particular sculpture with a humanistic spirit in many respects determines whether it will remain in people's memory as being outstanding or not. History tells us that the most outstanding sculptural works are all imbued with the spirit and sense of humanism, giving the viewer an incomparable experience of emotional feeling. As far as the eye can see, in modern and in classical sculpture, outstanding sculptors have been creating their own unique language of forms and contents, trying to convey emotions, human spirit and their search in art. Therefore, we, directly involved in the sculpture, are obliged to understand how the sculptor demonstrates the vision of a humanistic experience in his works; only by realizing this, understanding how this process has influenced the development of sculpture, we can improve sculpture creativity.

\section{REFERENCES}

1. Xu Jian. Spiritual and Emotional. Beijing: Beijing Chanu Yinshuaguan, 2003.

2. Cao Chun. The Principles of Emotionality in Sculpture. Shanda Zhongwenyi.

3. "Rodin and the Bust of Mrs. Russell". Translated by Fu Lei. // Jiechu Chubanshe, 2006 (2).

4. Zhang Chenhua. Sculpture. Zhongguo Diaosu Zazhi She.

5. Ho Boyan. A Bit Different from an Average Person. Features of the Realistic Style of Lou May's Sculpture. Meiyuan, 2012. 
Ли Бинь

Факультет изобразительных искусств Педагогический университет Внутренней Монголии e-mail:am_xiafei110@163.com 2. Хох-Хото, Внутренняя Монголия

ORCID 0000-0003-0637-1497

DOI: $10.36340 / 2071-6818-2019-15-4-136-146$

\section{Гуманистический дух в творчестве скульптора (на примере творчества Ли Сянцюня)}

Аннотация: Известному китайскому скульптору Ли Сянцюню удалось выработать в своей творческой манере уверенную и отточенную способность создания форм, особый и самобытный взгляд на действительность, мастерски овладеть изысканным выразительным языком скульптуры и создавать обладающие высокой духовной ценностью, наполненные духом времени и чувством гуманизма произведения. В данной работе путём анализа некоторых работ Ли Сянцюня и передачи читателю опыта чувственных ощущений в творчестве скульптора подчёркивается важность гуманистических факторов в скульптурном искусстве. Воплощение в материальной форме гуманистических ценностей есть дух и квинтэссенция изобразительной скульптуры. Это отличает изобразительную скульптуру как явление от рафинированного базового изображения реальности и является своего рода меркой, с которой необходимо соотносить творчество скульптора. Работы Ли Сянцюня требуют высочайшего внимания к себе, они - классический образец воплощения элементов гуманизма в скульптуре. Ли Сянцюнь получил всеобщее признание как лидер и подвижник в сфере современной китайской изобразительной скульптуры. Ему принадлежит неоспоримый вклад в развитие современного китайского скульптурного искусства и его гуманистического духа.

Ключевые слова: Ли Сянцюнь, фигуративная скульптура, образный язык скульптуры, гуманистический дух.

Вне зависимости от того, рассматриваем ли мы скульптурное произведение с позиций анализа формы и содержания или духовного наполнения, дух гуманизма является одной из важнейших её частей, своеобразной квинтэссенцией. Творец, не знающий как или не могущий выразить в своих произведениях чувства, весьма прискорбное и даже трагичное зрелище, ведь тогда его творчество теряет всякий смысл. Но в то же время искусство - это не только лучшая форма выражения чувств творца, но и опредёленная мера его ответственности перед обществом.

То, в чём нет чувства, духа, не может быть искусством, а дух гуманизма как раз и есть то, что пронизывает человеческое существо и всю его жизнь. При этом, 
будучи интерпретированным через призму скульптуры, он приобретает зримое и осязаемое выражение в виде скульптурного произведения. Гуманистический дух, содержащийся в произведении, есть то, что определяет успех этого произведения, - своего рода душа, которую в него вкладывает автор.

Творчество Ли Сянцюня - это один из флагманов современной фигуративной скульптуры Китая. Автор никогда не сосредотачивался на поверхностном, формальном выражении содержания - в его случае процесс скорее обратный: огромное внимание скульптор уделяет гуманистическому духу своих работ, который и определяет выразительные формы. Имея широкие исторические познания, Ли Сянцюнь обратился к опыту эпохи Родена, многие выдающиеся творцы которой добились высот именно потому, что смогли выразить в своих работах обширные философские идеи и ухватить дыхание самого времени. Именно в этом и заключается подлинная ценность и сущность скульптурного искусства.

Ли Сянцюню удалось объединить элементы восточного стиля се-и и анатомическую точность западной школы, создав ни на что не похожий, по-своему прекрасный стиль, в котором отразился дух времени.

В скульптуре «Вечное вращение» (рис. 1) Ли Сянцюнь не только изобразил метательницу диска, застывшую в момент броска, но и сумел символически показать энергию, жизненную силу человечества и прекрасный соревновательный дух Олимпийского движения. Если мы сравним эту скульптуру со знаменитым мироновским «Дискоболом», пришедшим к нам из Древней Греции, то увидим, что в «Вечном вращении» автору удалось выразить дух времени, не утратив при этом изящества классической восточной скульптуры. Метательница и её диск вместе образуют пространственную скульптуру, в которой застыл момент за секунду до броска, словно это момент вселенской гармонии, в котором мы видим пространственный образ вращения галактики. Это великолепная аллегория преемственности и вечной энергии человечества и Олимпийского движения, символ перерождения, в котором воплощается философия Востока.

Другая достойная внимания работа Ли Сянцюня - «Шаньсю», в которой соединились классическая западная форма и тонкое изящество глубокого восточного содержания. Скульптура демонстрирует образ простой и одухотворённой девушки. Плавные черты лица и глаза, уголки которых слегка загнуты вверх, создают ощущение безмолвия и задумчивости, передавая эстетически великолепный образ восточной девушки с её особым темпераментом. При взгляде на «Шаньсю» мы легко можем увидеть, что основой стиля Ли Сянцюня является точное изображение действительности.

Выработав особый выразительный язык в скульптуре и в совершенстве овладев им, Ли Сянцюнь создал новый стиль в искусстве, параллельно изыскивая в своём творчестве гуманистический дух. Его характерные работы привлекли внимание скульпторов всего мира, получили мировое признание и премии на круп- 
нейших международных выставках. Это послужило одной из причин того, что Ли Сянцюнь стал одной из наиболее узнаваемых деятелей китайского искусства. «Красная звезда нал Китаем» (рис. 3) - название книги американского журналиста Эдгара Сноу. Это биографические записи, в которых автор правдиво и с присущим ему революционным идеализмом описывал события Великого Похода Красной армии и совещания в Яньане. Прообразом человека, которого изображает одноимённая скульптура, послужил Мао Цзэдун. В его изображении отразился революционный идеализм западных левых интеллектуалов. Созданный скульптором образ во многом вдохновлён личностью Мао Цзэдуна, но это не просто изображение исторического персонажа - автор акцентировал внимание не на политическом величии отдельного человека, а на его личности, подлинном характере, и даже назвал работу иносказательно, с особой тщательностью передавая психологическое состояние, переживания Мао, что делает этот образ отличным от повседневной реальности. Автор сумел передать задумчивое и меланхоличное состояние Мао, чтобы и подчеркнуть его истинную сущность, ведь самое главное в человеке, будь он принц или нищий, - его внутренний мир. Именно поэтому образ Мао Цзэдуна так отличается от современного, многократно популяризированного и символизированного: разница - в психологической глубине изображения. Создавая эту скульптуру, Ли Сянцюнь не пожалел сил на полевые изыскания. Он побывал в Шэньбэе и Цзуаньяодуне, прошёл по местам славы председателя Мао, прочёл огромное количество мемуаров и исследований, посвящённых ему (как китайских, так и западных авторов). Таким образом скульптору удалось добиться невероятной достоверности и психологической правдивости. Если у нас не будет стремления к правдивому познанию и осмыслению истории - не может возникнуть определённое и чёткое историческое сознание. Нам нужно вновь и вновь обращаться к образу Мао Цзэдуна, чтобы лучше осмыслить историческую судьбу Китая.

Если взглянуть на следующую работу автора - «Лавина облаков и снега» (рис. 4), - где он изображает императрицу Цы Си, то она примечательна тем, что в ней автор демонстрирует ещё одну грань своего изобразительного таланта. Как правило, многие художники и скульпторы, изображая отрицательных персонажей, делают это в карикатурной манере. А Ли Сянцюнь впервые применил новый приём изображения исторических деятелей, который назвал «юньсань сюэсяо» (в переводе с китайского - «тающие облака и снег»), позволивший ему показать собственную трактовку взлётов и падений неоднозначной личности Цы Си. В некоторых течениях современного искусства бездумное увлечение формой породило «искусство ради искусства», заменив собою идейное содержание, однако Ли Сянцюню удалось вплести в форму современного искусства подлинный дух классики, продемонстрировать глубокий рациональный опыт связи скульптурных форм современного искусства и его содержания. В этом - самая большая мощь творческого наследия Ли Сянцюня: не просто отточенная техника, а проявляющийся в содержании его скульптур глубокий гуманистический дух. 
Недавняя серия работ Ли Сянцюня «Четыре юаньских мастера» стала ещё бо́льшим проявлением уважения автора к духу традиционного восточного искусства. Опираясь на своё восприятие культуры и искусства, Ли Сянцюнь создал эти образы - к примеру, «Хуан Гунван» (рис. 5), поза которого свидетельствует о том, что он создаёт картину, но словно не кистью, а идеей, подчёркивая стремление китайской традиционной живописи к идейности, или «Ван Мэн» (рис. 6), который изображён лёжа на боку в праздном созерцании, словно бы глубоко проникся замыслами и идеями древних мудрецов, словно это его передышка во время стихосочинения, в процессе которой он устремляется в прошлое, скрываясь от суеты настоящего.

В последние годы Ли Сянцюнь проявляет всё больший интерес к культуре и истории Китая, опираясь на собственный взгляд, вдыхая вторую жизнь в символические образы деятелей культуры прошлого, позволяя им войти в мировоззрение современных людей и формируя понимание многосторонней связи древности, современности, человека и его собственного «Я».

Заключение: Произведения искусства суть овеществлённый дух человечества, потому мы и говорим о том, что материальное должно быть воплощением духовного, - в противном случае искусство как таковое теряет всякий смысл. Произведения искусства обязаны содержать дух и чувственные вкусы людей, потому гуманистическое чувство есть своеобразная душа скульптурного произведения. Если взглянуть на художественное творчество именно так - как на носитель духа, - то крайне важными становятся его формы, его язык. С помощью языка форм скульптуры можно напрямую передать духовные, философские концепции, эмоции, чувства гуманизма. Наполнение конкретной скульптуры гуманистическим духом во многом определяет, останется ли она в памяти людей как выдающаяся. История свидетельствует, что все наиболее выдающиеся скульптурные произведения пропитаны духом и чувством гуманизма, давая зрителю ни с чем не сравнимый опыт чувственного переживания. Как в современной, так и в классической скульптуре выдающиеся мастера создавали собственный уникальный язык форм и содержаний, стремясь передать эмоции, дух человека и поиск собственного пути в искусстве. Потому мы обязаны понимать, каким образом скульптор в своих работах демонстрирует видение гуманистического переживания. И только осознав это, поняв, как шёл этот процесс по пути развития скульптуры, мы сможем совершенствовать скульптурное творчество.

\section{БИБЛИОГРАФИЯ}

1. Сюй Цзянь. Дух и эмоции. Пекин: Бэйцзин шану иньшуагуань, 2003.

2. Цао Чунь. Принципы эмоциональности в скульптуре // Шэнда чжунвэньи.

3. Роден и голова миссис Рассел / пер. Фу Лэй. // Цзечу чубаньшэ, 2006. № 2.

4. Чжан Чэньхуа. Скульптура // Чжунго дяосу цзачжи шэ.

5. Хо Боян. «Немного не такой, как обыватель»: особенности реалистического стиля скульптуры Лу Мэя. Мэйюань, 2012. 